\begin{tabular}{|c|c|c|}
\hline 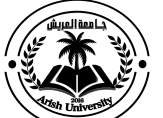 & $\begin{array}{l}\text { SCREENED By SINAI Journal of Applied Sciences } \\
\text { iThenticate }\end{array}$ & $\frac{\text { ARU-EGYPT }}{\text { SJAS }}$ \\
\hline
\end{tabular}

\title{
INFLUENCE OF MINERAL PHOSPHATE FERTILIZATION ON ACCUMULATION OF CADMIUM IN SOIL
}

\author{
Amira H. Ali ${ }^{*}$, E.R. Marzouk ${ }^{1}$ and M.A. Hassan ${ }^{1}$ \\ 1. Dept. Soil Sci., Fac. Environ. Agric. Sci., Arish Univ., Egypt.
}

\begin{abstract}
In this current work, the influence of mineral phosphate fertilization on accumulation of cadmium in soil was studied. Rock Phosphate (RP) and Triple super phosphate (TSP) were selected as a common source of $\mathrm{P}$ fertilizers and enriched by $\mathrm{Cd}$ contamination. An incubation experiment was undertaken for 60 days. Soil was incubated with RP or TSP with 0.0, 20.0, 40.0 and $80.0 \mathrm{~kg} \mathrm{P}_{2} \mathrm{O}_{5} \mathrm{ha}^{-1}$. Soil samples were then taken after 1, 3, 7, 15, 30 and 60 days from incubation course. The most important results gained from the current study were: $\mathrm{Cd}$ concentration in RP was enriched 87 times of crustal abundance where Cd concentration in TSP was enriched 73 times crustal abundance. Although the TSP produced higher available P comparing with RP, the differences were not significant. For both TSP and RP applications, $\mathrm{Cd}$ extracted by DTPA as a proxy of bioavailable pool of $\mathrm{Cd}$ in soil was increased by increasing the $\mathrm{P}$ fertilizer rates and by consequence of incubation period. A negative relationship between soil $\mathrm{pH}$ and DTPA-Cd has been obtained. The increase of Cd sorption in this study might be attributed to the increase of soil $\mathrm{pH}$ caused by the $\mathrm{P}$ additions. This might be obvious in the decreasing of DTPA-Cd under higher $\mathrm{pH}$ values. The $\mathrm{Cd}$ in TSP might be more readably available than that of RP. The concentration of DTPA-Cd in incubated soil increased slightly due to the application of phosphate fertilizers, but the concentration did not reach contamination levels under different treatments.
\end{abstract}

Key words: Phosphate fertilization, cadmium, Rock Phosphate, Triple super phosphate.

\section{INTRODUCTION}

Cadmium $(\mathrm{Cd})$ is a trace element that is naturally present in soils, but can also be introduced into soil through atmospheric deposition, industrial contamination, sewage sludge, irrigation water, and agricultural inputs such as manures, fertilizers, and soil amendments. Agricultural crops accumulate $\mathrm{Cd}$ from the soil, with the amount of uptake depending on several factors, including crop genetics, soil $\mathrm{Cd}$ concentration, and Cd phytoavailability, which is affected by soil characteristics.

Long-term consumption of foods containing excess levels of $\mathrm{Cd}$ may lead to chronic toxicity and adverse health effects.
Phosphorus (P) is an essential nutrient for crop production and growth. Next to nitrogen, phosphate is by far the most limiting nutrient for crop production. Phosphate is essential for plant growth and maintaining agricultural productivity. It is a nutrient required in relatively large amounts by plants. Plants need phosphorus for growth, utilization of sugar and starch, photosynthesis, nucleus formation and cell division, fat and albumen formation (Hinsinger et al., 2018). Phosphorus is a component of the complex nucleic acid structure of plants, which regulates protein synthesis (Smith et al., 2018). Phosphorus is, therefore, important in cell division and development of new tissue. Phosphorus is

\footnotetext{
* Corresponding author: Tel.: +201064978708

E-mail address: amirahassan_ali@yahoo.com
} 
also associated with complex energy transformations in the plant. Adding phosphorus to soil low in available phosphorus promotes root growth and winter hardiness, stimulates tillering, and often hastens maturity. For soils deficient in $\mathrm{P}$, application of organic or inorganic fertilizers is needed to achieve optimum crop yields. Although P fertilizers represent the major anthropogenic input of $\mathrm{P}$ to agricultural soils, both inorganic $\mathrm{P}$ fertilizers and organic $\mathrm{P}$ sources, such as sewage sludge and manure, may contain $\mathrm{Cd}$. In addition to direct inputs of $\mathrm{Cd}$, phosphate fertilization can indirectly affect $\mathrm{Cd}$ accumulation in soil through its effects on soil chemistry and microbial interactions. Therefore, the management of $\mathrm{P}$ fertilizer application, both in the short and long term, can influence the potential accumulation of $\mathrm{Cd}$ in foods.

Rock Phosphate RP is an essential resource for the production of phosphate fertilizers. RP is being imported from various sources around the world. Morocco rock phosphate has three quarters of the world phosphate reserves (Bilali et al., 2005). The various phosphate minerals present in RP have diverse origins and chemical and physical properties. The phosphorus content or grade of rock phosphate is commonly reported as phosphorus pentoxide $\left(\mathrm{P}_{2} \mathrm{O}_{5}\right)$. The principal phosphate minerals in RP are Caphosphates, mainly apatites. Pure fluorapatite contains $42 \% \quad \mathrm{P}_{2} \mathrm{O}_{5}$, and francolite, the carbonate-substituted form of apatite, may contain $34 \% \mathrm{P}_{2} \mathrm{O}_{5}$.

The RP is, due to its origin, affected by high concentrations of impurities, heavy metals, naturally occurring radionuclides and other so-called trace elements (Selim, 2018). Lowering the cadmium content in fertilizers is the only feasible way of reducing the cadmium input to farmland from this source. This can be achieved either by using raw materials (RP) with a lower cadmium content, or by eliminating the cadmium from the RP or the phosphoric acid during the production process. Obviously, the flow of cadmium to agricultural soils can also be reduced by applying lower amounts of phosphate fertilizer and/or substituting fertilizers by other products containing phosphorus e.g. manure (Mar, 2012). The main object of this work was to study, the influence of mineral phosphate fertilization on accumulation of cadmium in soil.

\section{MATERIALS AND METHODS}

A lab experiment was carried out at the Experimental lab of Environ. Agric. Sci. Fac., Arish University, North Sinai, Egypt. Top $20 \mathrm{~cm}$ soil sample was collected from the research farm of the Faculty of Environmental Agricultural Sciences, Arish University, North Sinai, Egypt. Soil sample was air dried, ground with a wooden mallet and passed through a $2 \mathrm{~mm}$ sieve and stored in clean dry plastic bags for various physical and chemical analyses.

Air dried soil samples, $<2 \mathrm{~mm}$ were mixed with $0.149-\mathrm{mm}$ sieve $\mathrm{P}$ fertilizer. The experiment was performed in two treatments and triplicate replicates per treatment. Each treatment has been applied for different rates. RP or TSP was homogeneously mixed with $100 \mathrm{~g}$ of airdried soil at $0.0,20.0,40.0$ and $80.0 \mathrm{~kg}$ $\mathrm{P}_{2} \mathrm{O}_{5} \mathrm{~h}^{-1}$. The water content of the soil was adjusted to approximately $60 \%$ of water holding capacity by adding double distilled water with an automatic pipette and was placed in a $250 \mathrm{ml}$ plastic bottle. The bottles were then kept in lab at $25^{\circ} \mathrm{C}$. Throughout the incubation period, water losses exceeding $10 \%$ of the initial values were compensated by addition of water by weight to avoid soil- solution system disturbance. Soil samples were taken after $1,3,7,15,30$ and 60 days from incubation course, oven dried and prepared for analysis. Soil pH, EC, Olsen P, DTPA-Cd were measured. 


\section{Phosphorous measurements}

Phosphate was extracted with $0.5 \mathrm{M}$ sodium bicarbonate $\left(\mathrm{NaHCO}_{3}\right)$ solution at pH 8.5 (Olsen et al., 1954) as available $\mathrm{P}$ and from digested soil as total $\mathrm{P}$. both solutions were assayed using a variation on the phosphomolybdate method (Drummond and Maher, 1995) by measuring absorbance in a $1 \mathrm{~cm}$ cell at $660 \mathrm{~nm}$ (CE 1011 spectrophotometer, Cecil Instruments). All soil measurements were repeated in triplicates and the average results were reported.

Triplicate samples of $4.0 \mathrm{~g}$ soil $(<2 \mathrm{~mm}$ sieved) were suspended in $8 \mathrm{ml}$ of $0.005 \mathrm{M}$ DTPA (Lindsay and Norvell, 1978) and shaken on an end-over-end shaker, in Oak Ridge polypropylene centrifuge tubes, for 2 hours. Suspensions were then centrifuged at $2500 \mathrm{rpm}$ for $15 \mathrm{~min}$ and the supernatant filtered $(<0.2 \mu \mathrm{m})$ into polyethylene tubes containing sufficient $\mathrm{HNO}_{3}$ to produce $2 \%$ acid prior to multi-element analysis by ICP-MS.

\section{RESULTS AND DISSUTION}

\section{General soil characteristics}

The tested soil was sandy in nature with $4.5 \%$ clay, $2.3 \%$ silt and $93.2 \%$ sand fractions. Soil $\mathrm{pH}$ was close to neutral with alkaline effect. Soil EC was $0.30 \mathrm{dSm}^{-1}$ with tiny amount of $\mathrm{CaCO}_{3}(0.05 \%)$. Soil organic matter was very low $(0.01 \%)$ due to arid conditions. Total metal concentrations in acid digest soil were varied depending on specific element. Total Cadmium concentration is $0.101 \mathrm{mgkg}^{-1}$ which in the range of the earth's crust level considering the tested soil as uncontaminated soil (low background level of $\mathrm{Cd}$ ).

\section{General characteristic of $\mathbf{P}$ fertilizers}

The results showed that RP and TSP have a significant amount from $\mathrm{Cd}$. This will defiantly be reflected on the accumulation of $\mathrm{Cd}$ in soil. The $\mathrm{Cd}$ total concentrations measured in acid digest fertilizer were 23.2 and $19.5 \mathrm{mgkg}^{-1}$ for RP and TRP, respectively.

\section{Soil Available P}

An incubation experiment has been conducted for 60 days. The available $\mathrm{P}$ was measured after $1,3,7,15,30$ and 60 days from incubation course (Fig. 1). Depending on the general average values of available $\mathrm{P}$ (Fig. 2). The results showed that available $\mathrm{P}$ increased up to 7 days of incubation course which rich the maximum value of $6.05 \mathrm{mg}$ $\mathrm{kg}^{-1}$ for RP treatments then the value was declined till the end of incubation course. However, Available $\mathrm{P}$ in case of TSP treatment started to decrease from the beginning till the end of incubation course (Fig. 2). The average Olsen $P$ obtained from treating the soil with TSP was $5.74 \pm 0.48$ which is a little higher than the same value obtained from treating the soil with RP (average Olsen $\left.\mathrm{P}\left(\mathrm{P}_{2} \mathrm{O}_{5}\right)=5.38 \pm 0.44\right)$. Although the TSP produced higher available $\mathrm{P}$ comparing with RP, the differences were not significant; the $T$ paired test showed probability of 0.26 and $T$ value of -1.26 . In contrast, the rate of $\mathrm{P}$ added to the soil has a significant effect in available $\mathrm{P}$ in both $\mathrm{P}$ fertilizer. In general, As the mobile and easily mineralizable fraction of $\mathrm{P}$ for plant use, the concentration of Olsen $\mathrm{P}$ in the end of incubation course increased significantly as compared to the values at the beginning of incubation period in all $\mathrm{P}$ fertilizer addition rates $(\mathrm{p}<0.05)$.

\section{DTPA extractable Cd}

The results of DTPA-Cd were presented in Fig. 3. The results showed that, for both TSP and RP application, Cd extracted by DTPA as a proxy of bioavailable pool of $\mathrm{Cd}$ in soil was increased by increasing the $\mathrm{P}$ fertilizer rates and by consequence of incubation period. However, the final DTPA-Cd values obtained at the end of incubation period were higher than that at control. In terms of $P$ release rose rapidly at the initial time of incubation period 


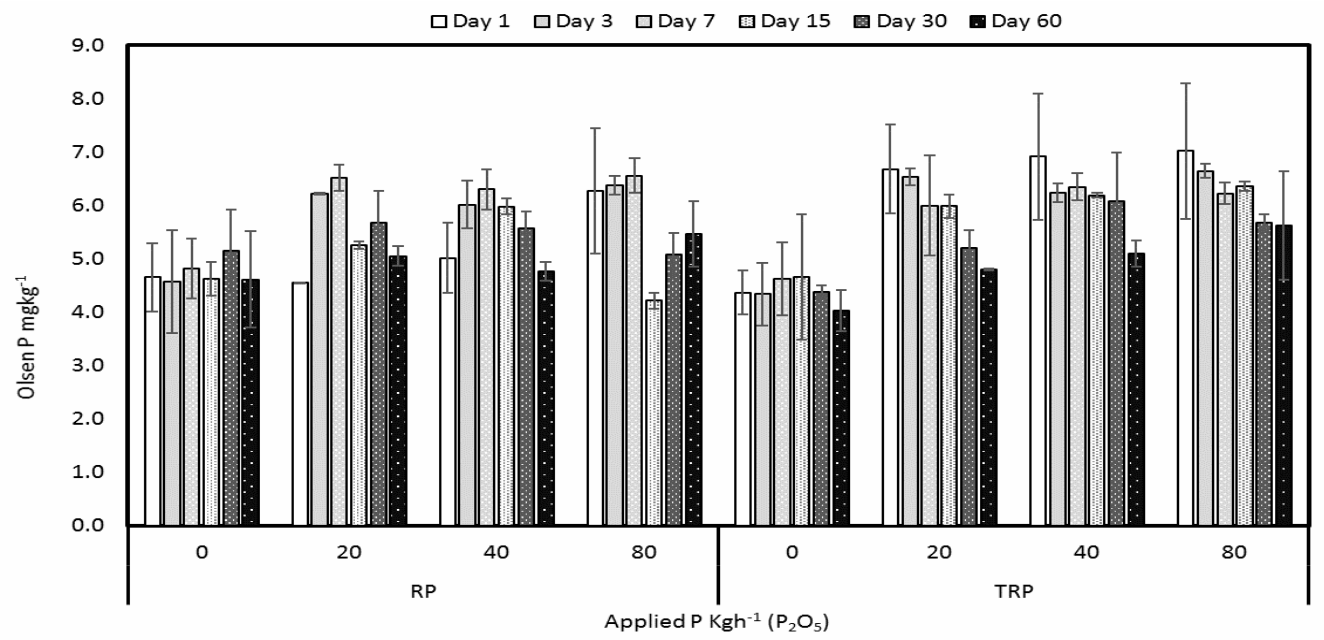

Fig. (1): Changes of available $P$ (Olsen $P$; $m g P_{2} O_{5} k g g_{=}^{1}$ ) in tested soil as a function of $P$ sources (RP; rock phosphate and TSP; triple superphosphate) at $0,20,40$ and $80 \mathrm{~kg} \mathrm{P}_{2} \mathrm{O}_{5} \mathrm{~h}^{-1}$ during the incubation course $(1,3,7,15,30$ and 60 days). Error bar represents the standard error of triplicates.

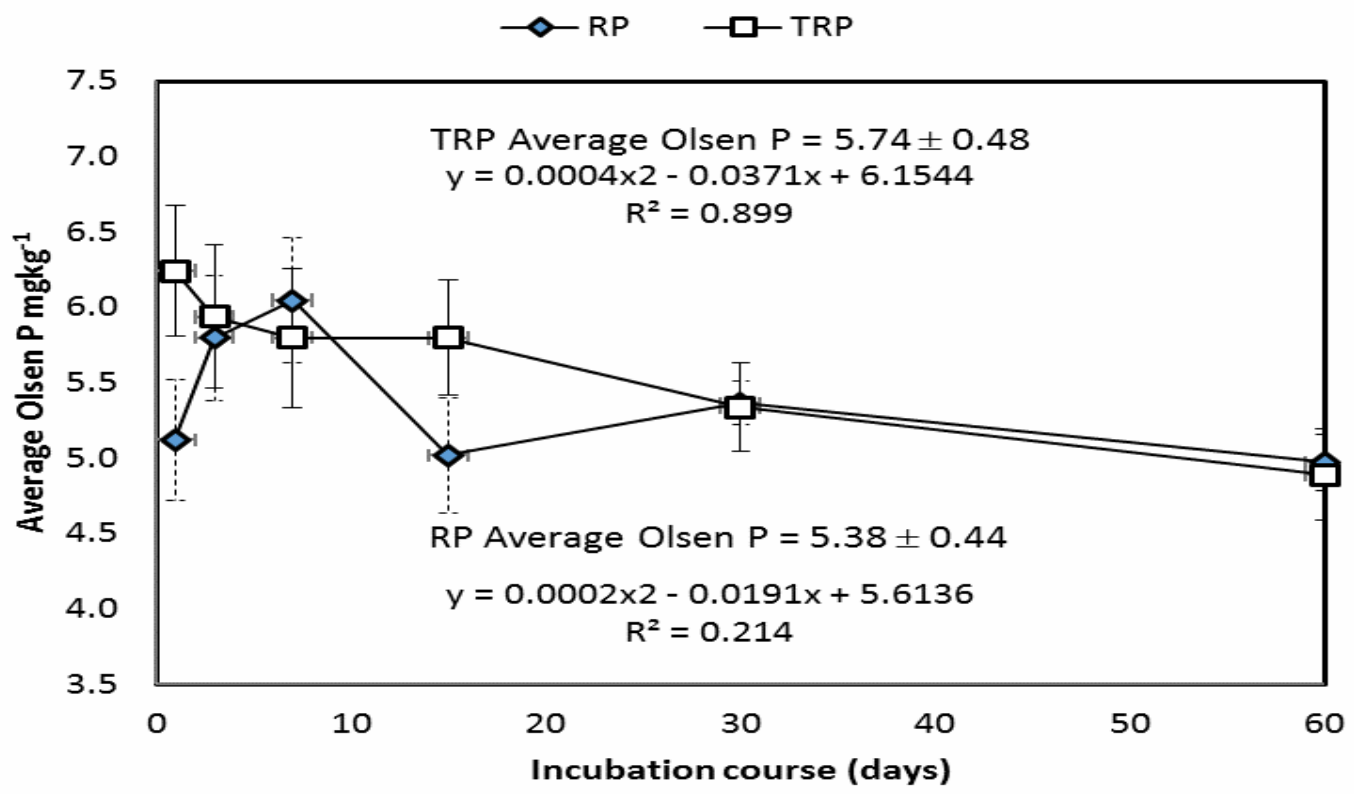

Fig. (2): General average changes of available $P$ (Olsen $P$ mg $\mathrm{P}_{2} \mathrm{O}_{5} \mathrm{~kg}^{-1}$ calculated by averaging all values driven from different concentrations of applied $P$ fertilizers) in tested soil treated by rock phosphate (RP) and triple superphosphate (TSP) as a function of incubation course. Error bar represents standard error of triplicates. 


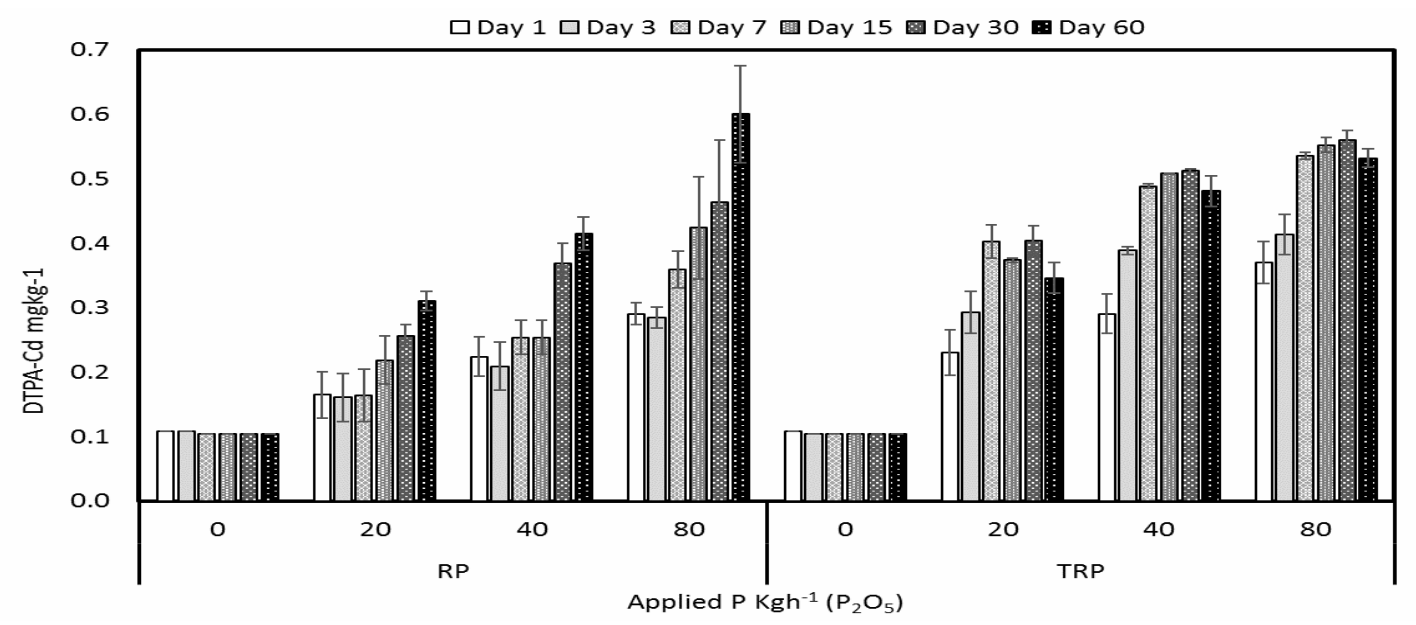

Fig. (3): Changes of available (mg DTPA-Cd kg-1) in tested soil as a function of $P$ sources (RP; rock phosphate and TSP; triple superphosphate) at $0,20,40$ and $80 \mathrm{~kg} \mathrm{P}_{2} \mathrm{O}_{5} \mathrm{~h}^{-1}$ during the incubation course $(1,3,7,15,30$ and 60 days). Error bar represents the standard error of triplicates.

(typically one day), as expected, and like the Cd, (Figs. 1 and 3). It seems after 60 days of incubation course, the application rate of $80 \mathrm{~kg} \mathrm{P}_{2} \mathrm{O}_{5} \mathrm{~h}^{-1}$ of $\mathrm{RP}$ had the highest DTPA-Cd value followed by the same rate of TSP at the end of incubation period as well. General results showed average DTPA-Cd obtained from treating the soil with TSP was $0.347 \pm 0.063 \mathrm{mg}$ DTPA-Cd $\mathrm{kg}^{-1}$ which is a little higher than the same value obtained from treating the soil with RP (DTPA-Cd $=2.53 \pm 0.063$ ) (Fig. 4). The difference between RP and TSP in terms of producing DTPA-Cd in soil were significant where T-Paired test showed probability of 0.009 and $\mathrm{T}$ value of -4.12 .

Moreover, the best fitting relationship between an average DTPA-Cd and incubation intervals was liner for RP $(y=0.0028 x+$ 0.198 ) with $R^{2}$ of 0.97 where it was polynomial $2^{\text {nd }}$ order equation $(\mathrm{y}=-0.0001 \mathrm{x} 2$ $+0.008 \mathrm{x}+0.2803)$ with $\mathrm{R}^{2}$ of 0.71 .

The current incubation experiment showed the importance of understanding the release of $\mathrm{Cd}$ from fertilizer in unsaturated soils (Yu et al., 2019). Under typical field conditions it is expected that only about $10-20 \%$ of $\mathrm{Cd}$ will be released quickly in soluble form and that most of the
Cd will remain associated with very slowly dissolving solids (Piveteau, 2017).

\section{Soil pH and EC}

Fig. 5 shows the relationship between DTPA-Cd and soil $\mathrm{pH}$. The results showed a negative relationship between soil $\mathrm{pH}$ and DTPA-Cd. Soil pH directly and indirectly influences all chemical processes, and consequently the behavior of trace elements in soils (Wang et al., 2006). Soil $\mathrm{pH}$ is an important factor in affecting sorption and desorption of heavy metals by soil (Kunhikrishnan et al., 2012).

Shaheen (2009) reported that the total amounts of $\mathrm{Pb}$ and $\mathrm{Cd}$ sorbed within the concentration range used in the sorption experiments were larger in alkaline than in acidic soils from Egypt and Greece which is in consequence in the current results. The increase of $\mathrm{Cd}$ sorption in this study might be attributed to the increase of soil $\mathrm{pH}$ caused by the $\mathrm{P}$ additions. This might be obvious in the decreasing of DTPA-Cd under higher $\mathrm{pH}$ values (Fig. 5). Other researchers also reported that the sorption of $\mathrm{Pb}, \mathrm{Zn}$, and $\mathrm{Cd}$ by variable charge soils was $\mathrm{pH}$ dependent (Shaheen and Tsadilas, 2010, Cui et al., 2014, Li et al., 2018). An increase in soil $\mathrm{pH}$ causes deprotonatin of 


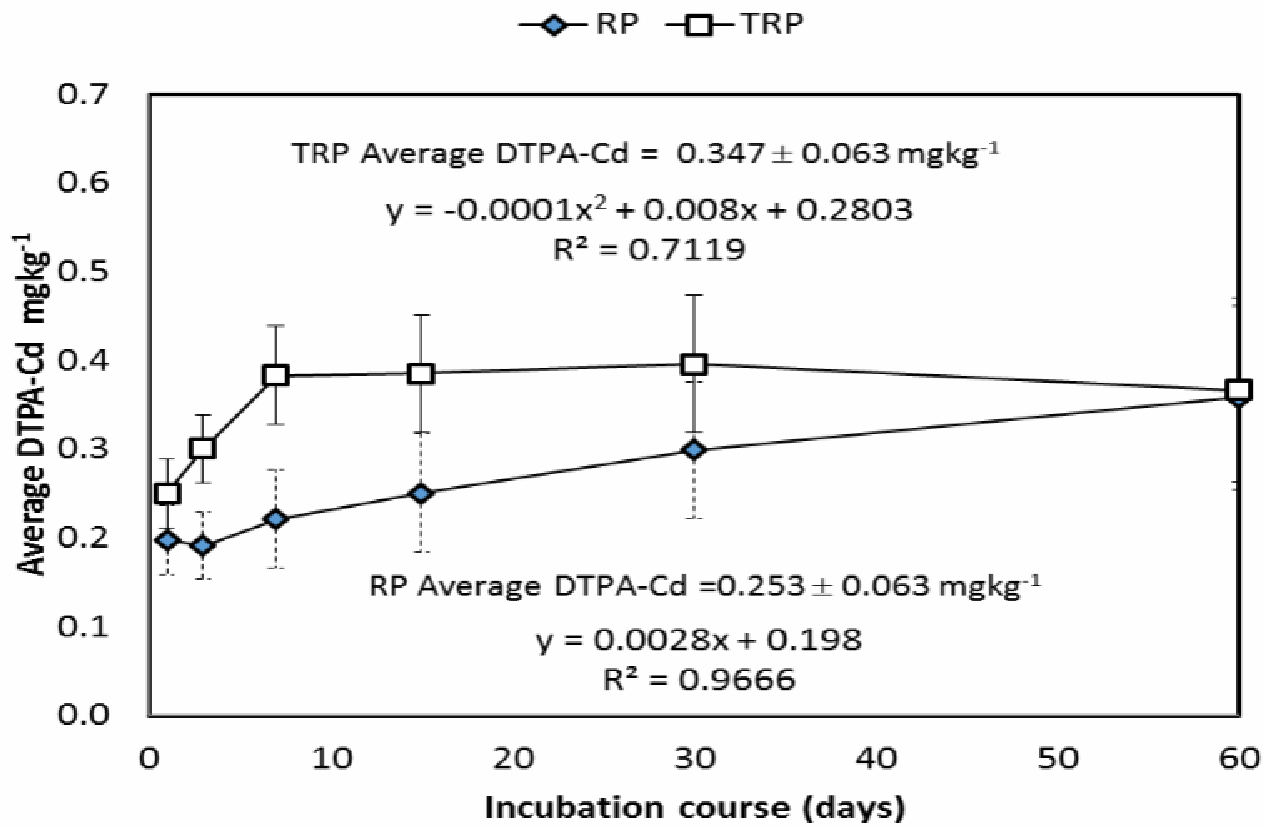

Fig. (4): General average changes of ( $\mathrm{mg}$ DTPA-Cd $\mathrm{kg}^{-1}$ ) calculated by averaging all values driven from different concentrations of applied $P$ fertilizers in tested soil treated by rock phosphate (RP) and triple superphosphate (TSP) as a function of incubation course. Error bar represents standard error of triplicates.

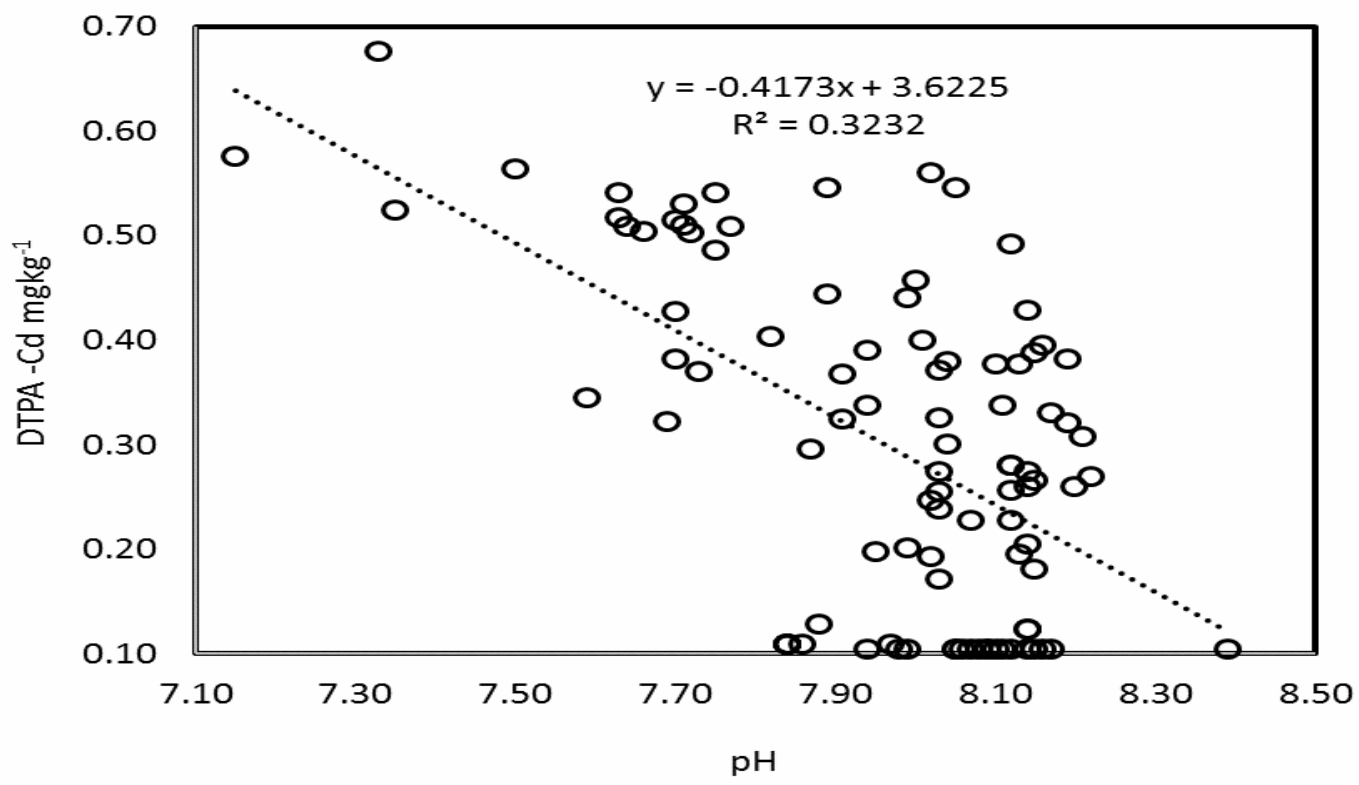

Fig. (5): Relationship between (mg DTPA-Cd $\mathrm{kg}^{-1}$ ) and soil $\mathrm{pH}$ for the whole dataset. Broken line represents liner relationship. 
hydroxyl groups on the surface of iron and aluminum oxides, and thereby, results in the increase of variable negative charges on soil colloid surfaces. More variable negative charges could attract more $\mathrm{Cd}$ toward soil surfaces through electrostatic attraction (Christensen, 1984), thereby, enhancing heavy metal ions sorption by soil clay minerals or iron and aluminum oxides.

On the other hand, increasing soil $\mathrm{pH}$ accelerated the transformation of $\mathrm{Cd}$ from $\mathrm{M}^{+2}$ to $\mathrm{MOH}^{+}$and $\mathrm{M}(\mathrm{OH})_{2}$ through hydrolysis, decreased the energy obstacle of the two ions to bind to soil oxides surface, and then increased the specific sorption by soil colloid surface (NAIDU et al., 1994).

Furthermore, increasing soil $\mathrm{pH}$ also allowed $\mathrm{Cd}$ to form stable complexes with Soil organic matter (SOM) and manganese oxides, and then increased their sorption by soil. Ma et al. (2010) reported that with increasing $\mathrm{pH}$, more $-\mathrm{COOH}$ and $-\mathrm{OH}$ in soil colloids dissociated to form -COO- and -O-, which can increase the ability of SOM to complex with $\mathrm{M}^{+2}$, and thus, increase the sorption of $\mathrm{M}^{+2}$.

The Cd release is mirrored in the soil during incubation periods by a very similar time course for electrical conductivity (EC) (Fig. 6), which is an index of total salts released from the fertilizer.

$\mathrm{EC}$ is a measure of the total concentration of dissolved ions. As expected, the largest increase in EC is seen in the experiment with the high fertilizer rate. This finding could be embedded in Fig. 6 where DTPA$\mathrm{Cd}$ mirror the total amount of $\mathrm{P}$ added to the soil. The EC values tracked the DTPA$\mathrm{Cd}$ values where slightly positive nonsignificant relationship has been found between DTPA-Cd and EC. The high EC values noted with solution could be due to the dissolved ions in the eluting solution itself .

Unexpected results have been found in the relationship between available $\mathrm{P}$ and EC as it was expected that increasing EC was a result of increasing the rate of fertilizers (Fig. 7). These unexpected results could be attributed from influence of different soil properties such as $\mathrm{CaCO}_{3}$, soil organic matter, $\mathrm{Fe}, \mathrm{Mn}$ oxides (Marzouk et al., 2013). Overall, applying both TRP and RP to the soil increased $\mathrm{Cd}$ concentration extracted by DTPA. Fig. 8 shows the relationship between DTPA-Cd and Applied P as TR and TRP at different rates. The results showed highly significant liner relationship $(p<0.01)$ for both fertilizers. Moreover, the average values of DTPA-Cd under TRP application $\left(0.35 \pm 0.06 \mathrm{mg} \mathrm{kg}^{-1}\right)$ were much higher than that of RP $\left(0.25 \pm 0.06 \mathrm{mgkg}^{-1}\right)$ although the total amount of Cd in RP $\left(23.2 \mathrm{mg} \mathrm{kg}^{-1}\right)$ is more than Cd exist in TRP (19.5 $\left.\mathrm{mgkg}^{-1}\right)$.

This finding may suggest that the $\mathrm{Cd}$ in TRP might be more readably available than that of RP. Rock Phosphate reactivity is a measure of the rate of dissolution of phosphate rocks under standard laboratory conditions or in a given soil and under given field conditions (Rajan and Chien, 2001). The dissolution rate of phosphate rocks is mostly affected by soil properties and plant characters. The chemical composition and particle size of phosphate rocks control their reactivity.

Sedimentary origin phosphate rocks are generally most reactive and suitable for direct application. Calcium carbonate is the most abundant accessory mineral in phosphate rocks.

As calcium carbonate is more soluble than the most chemically reactive phosphate mineral, its dissolution increases the calcium content and $\mathrm{pH}$ at the phosphate mineral surface. So, calcium carbonate can reduce the rate of phosphate rock dissolution in some soils. Sedimentary phosphate rocks show a very complex structure as a result of their different origin in nature and even within a particular geological deposit. Thus, they have extremely variable chemical 


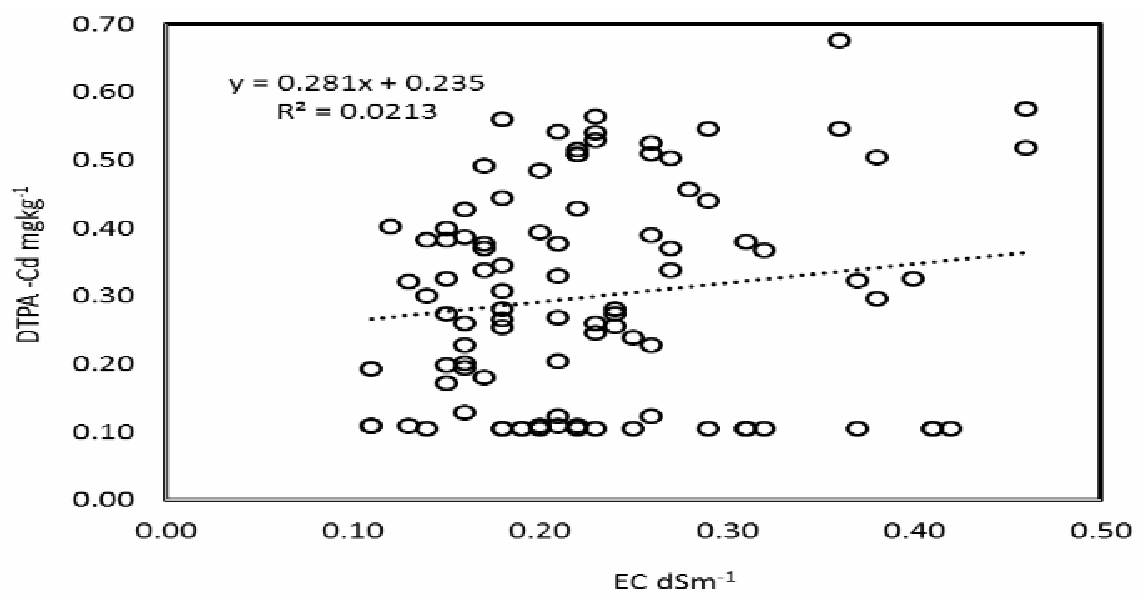

Fig. (6): Relationship between (mg DTPA-Cd $\mathrm{kg}^{-1}$ ) and soil EC $\left(\mathrm{dSm}^{-1}\right)$ for the whole dataset. Broken line represents liner relationship.

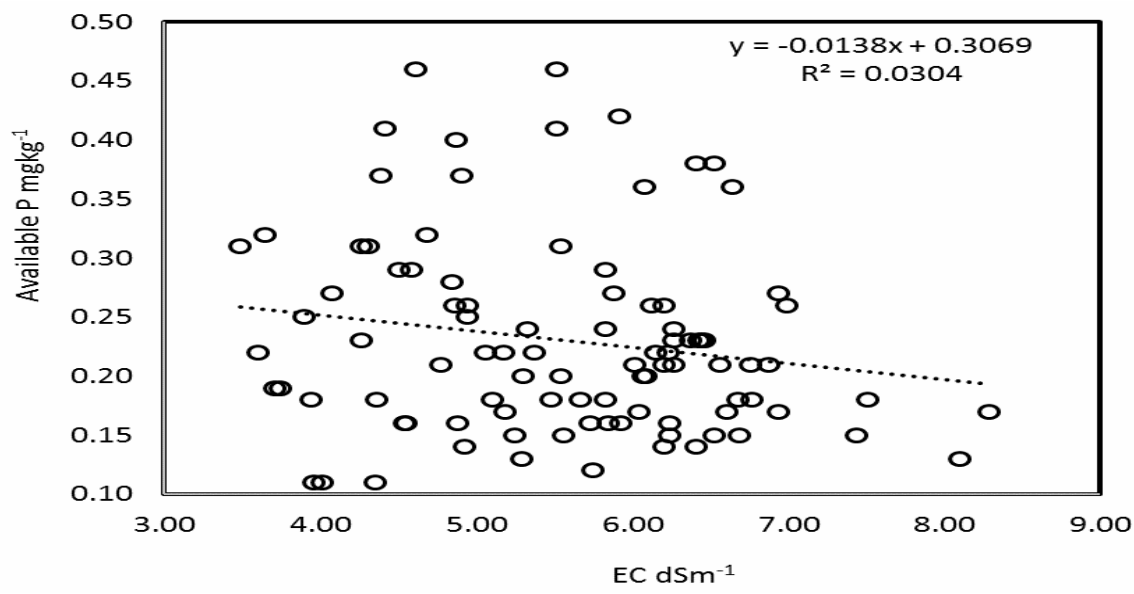

Fig. (7): Relationship between available $P\left(m g P_{2} \mathrm{O}_{5} \mathrm{~kg}^{-1}\right)$ and soil $\mathrm{EC}\left(\mathrm{dSm}^{-1}\right)$ for the whole dataset. Broken line represents liner relationship.

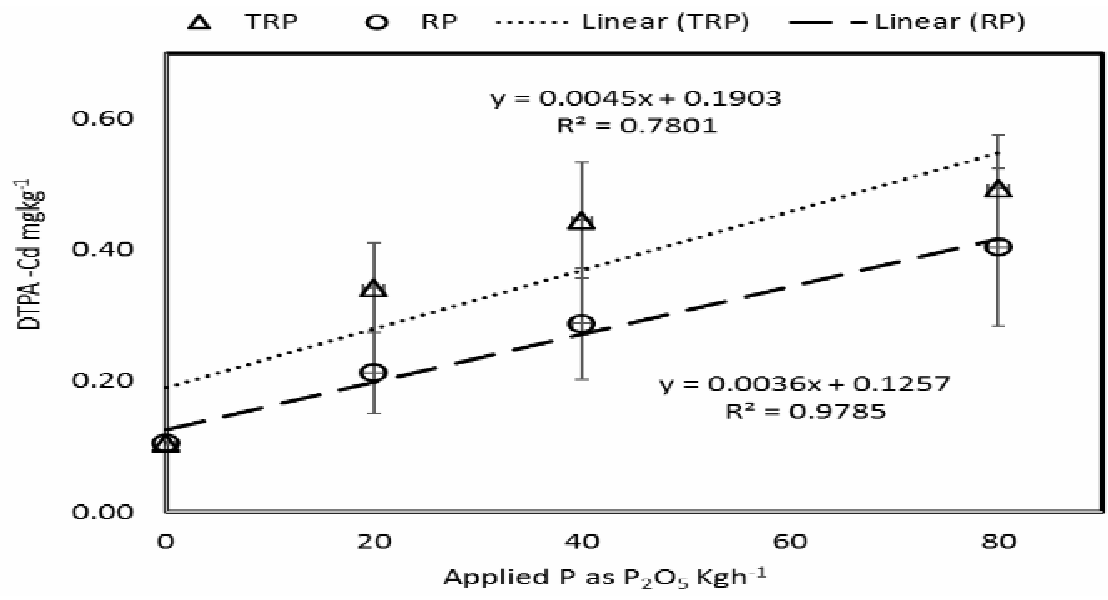

Fig. (8): Relationship between average (mg DTPA-Cd $\mathrm{kg}^{-1}$ ) values and total soil $P$ (kg $\mathrm{P}_{2} \mathrm{O}_{5} \mathrm{~h}^{-1}$ ) for the TR and TSP applications. 
constituents and may contain elements such as heavy metals and even radionuclides that upon dissolution of the phosphate rock in the soil may be harmful at some concentrations (Hellal et al., 2019). This could explain the highest level of extractable $\mathrm{Cd}$ by diluted DTPA gained from soil treated by TRP comparing to extractable $\mathrm{Cd}$ by diluted DTPA from the soil treated by RP.

Correlation coefficient matrix has been used for multi correlation analysis using principle component analysis (Table 1). The results show that a significant negative correlation between $\mathrm{pH}$ and $\mathrm{Cd}$ measured in DTPA solution, DTPA-Cd and TP added to the soil $(\mathrm{p}<0.01)$. Moreover, available $\mathrm{P}$ had a positive significant correlation with $\mathrm{Cd}$ measured in DTPA solution, DTPA-Cd and TP added to the soil ( $p<0.01)$. in addition, it has been observed that a significant positive correlation between DTPA-Cd and TP which confirm the source of $\mathrm{Cd}$ was obtained from the added $\mathrm{P}$ fertilizers.

Table (1): Correlation matrix between all measurements in incubation experiment.

\begin{tabular}{|c|c|c|c|c|c|}
\hline Item & $\mathbf{P H}$ & EC dsm ${ }^{-1}$ & Avi. P mgkg $^{-1}$ & $\mathrm{Cd} \mathrm{mgL}^{-1}$ & DTPA-Cd mgkg $^{-1}$ \\
\hline EC $\mathrm{dsm}^{-1}$ & $\begin{array}{c}-0.319 \\
0.027\end{array}$ & & & & \\
\hline Avi. $\mathbf{P}$ & $\begin{array}{l}0.023 \\
0.875\end{array}$ & $\begin{array}{l}-0.27 \\
0.064\end{array}$ & & & \\
\hline $\mathrm{Cd} \mathrm{mgL}^{-1}$ & $\begin{array}{c}-0.689 \\
0.000\end{array}$ & $\begin{array}{l}0.201 \\
0.171\end{array}$ & $\begin{array}{l}0.442 \\
0.002\end{array}$ & & \\
\hline DTPA-Cd mgkg ${ }^{-1}$ & $\begin{array}{c}-0.688 \\
0.001\end{array}$ & $\begin{array}{l}0.192 \\
0.192\end{array}$ & $\begin{array}{l}0.448 \\
0.001\end{array}$ & $\begin{array}{c}1 \\
0.000\end{array}$ & \\
\hline TP mgkg $^{-1}$ & $\begin{array}{c}-0.443 \\
0.002\end{array}$ & $\begin{array}{l}-0.03 \\
0.842\end{array}$ & $\begin{array}{l}0.523 \\
0.000\end{array}$ & $\begin{array}{l}0.757 \\
0.000\end{array}$ & $\begin{array}{l}0.762 \\
0.000\end{array}$ \\
\hline
\end{tabular}

\section{REFERENCES}

Bilali, L.; Benchanaa, M.; Mokhlisse, A. and Outzourhit, A. (2005). A detailed study of the microwave pyrolysis of the Moroccan (Youssoufia) rock phosphate. J. Anal. and Appl. Pyrolysis, 73: 1-15.

Christensen, T.H. (1984). Cadmium soil sorption at low concentrations: I. Effect of time, cadmium load, $\mathrm{pH}$, and calcium. Water, Air and Soil Pollution, 21 (1-4): 105-114.

Cui, H.; Zhou, J.; Si, Y.; Mao, J.; Zhao, Q.; Fang, G. and Liang, J. (2014). Immobilization of $\mathrm{Cu}$ and $\mathrm{Cd}$ in a contaminated soil: one-and four-year field effects. J. Soils and Sediments, 14: 1397-1406.

Drummond, L. and Maher, W. (1995). Determination of phosphorus in aqueous- solution via formation of the phosphoantimonylmolybdenum blue complex - reexamination of optimum conditions for the analysis of phosphate. Anal. Chim. Acta, 302: 69-74.

Hellal, F.; El-Sayed, S.; Zewainy, R. and Amer, A. (2019). Importance of phosphate pock application for sustaining agricultural production in Egypt. Bulletin of the Nat. Res. Cent., 43: 11. 
Hinsinger, P.; Herrmann, L.; Lesueur, D.; Robin, A.; Trap, J.; Waithaisong, K. and Plassard, C. (2018). Impact of roots, microorganisms and microfauna on the fate of soil phosphorus in the rhizosphere. Ann. Plant Rev. Online, 377-407.

Kunhikrishnan, A.; Bolan, N.S.; Müller, K.; Laurenson, S.; Naidu, R. and Kim, W.I. (2012). The influence of wastewater irrigation on the transformation and bioavailability of heavy metal (loid) $\mathrm{s}$ in soil. Adv. Agron., Elsevier.

Li, S.; Wang, M.; Zhao, Z.; Ma, C. and Chen, S. (2018). Adsorption and desorption of $\mathrm{Cd}$ by soil amendment: Mechanisms and environmental implications in field-soil remediation. Sustainability, 10: 2337.

Lindsay, W.L. and Norvell, W.A. (1978). Development of a DTPA soil test for zinc, iron, manganese, and copper. Soil Sci. Soc. Ame. J., 42: 421-428.

Ma, L.; Xu, R. and Jiang, J. (2010). Adsorption and desorption of $\mathrm{Cu}(\mathrm{II})$ and $\mathrm{Pb}$ (II) in paddy soils cultivated for various years in the subtropical China. J. Environ. Sci., 22: 689-695.

Mar, S.S. (2012). Characterization of phosphate rocks/fertilizers and their effects on $\mathrm{Cd}$ uptake by Komatsuna (Brassica rapa var. perviridis) and spinach (Spinacea oleracea) grown on melanudand and haplaquept. Tokyo Univ. Agric. and Technol.

Marzouk, E.R.; Chenery, S.R. and Young, S.D. (2013). Predicting the solubility and lability of $\mathrm{Zn}, \mathrm{Cd}$, and $\mathrm{Pb}$ in soils from a minespoil-contaminated catchment by stable isotopic exchange. Geochimica et Cosmochimica Acta, 123: 1-16.

Naidu, R.; Bolan, N.S.; Kookana, R.S. and Tiller, K.G. (1994). Ionic-strength and $\mathrm{pH}$ effects on the sorption of cadmium and the surface charge of soils. Eur. J. Soil Sci., 45: 419-429.
Olsen, S.R.; Cole, C.V.; Watanabe, F.S. and Dean, L.A. (1954). Estimation of available phosphorus in soils by extraction with sodium bicarbonate. US, Dept. Agric. Circ., 939.

Piveteau, S. (2017). Optimizing hydrolysis and acidogenesis in order to dissolve and recover phosphorus in organic effluents upstream from methane production. Univ. Rennes 1.

Rajan, S. and Chien, S. (2001). Published. Direct application of phosphate rock and related technology: latest developments and practical experiences. Proc. Int. Meeting, 2001.

Selim, H.M. (2018). Phosphate in Soils: Interaction with Micronutrients, Radionuclides and Heavy Metals, CRC Press.

Shaheen, S. and Tsadilas, C. (2010). Influence of fly ash and sewage sludge application on cadmium and lead sorption by an acidic Alfisol. Pedosphere, 20: 436-445.

Shaheen, S.M. (2009). Sorption and lability of cadmium and lead in different soils from Egypt and Greece. Geoderma, 153: 61-68.

Smith, A.P.; Fontenot, E.B.; Zahraeifard, S. and DiTusa, S.F. (2018). Molecular components that drive phosphorusremobilisation during leaf senescence. Ann. Plant Rev. Online, 159-186.

Wang, Y.Y.; H. Wen; X.Y. Shi and S.Q. Wei (2006). Research on the thermodynamics and kinetics of adsorption- desorption of cadmium on the different soil colloids. J. of Safety and Environ. Anquan $\mathrm{Yu}$ Huanjing Xuebao, 6: 72-76.

Yu, Y.; Xiong, J.; Liu, R. and He, Z. (2019). Release of heavy metals from dolomite phosphate rock after activation with organic agent. J. Environ. Quality. 


$$
\begin{aligned}
& \text { الملخص العربي }
\end{aligned}
$$

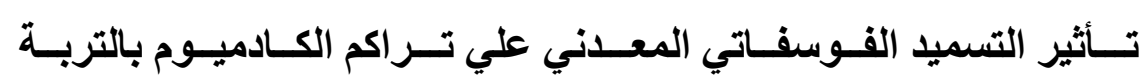

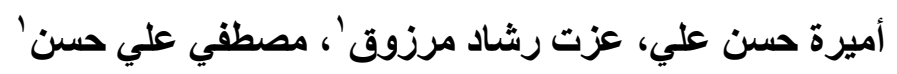

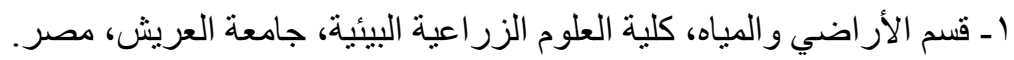

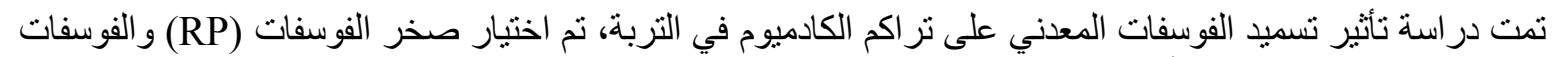

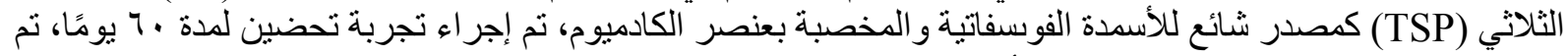

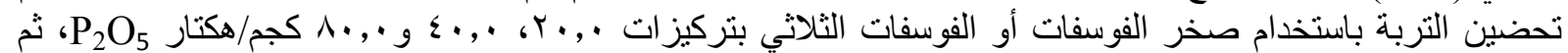

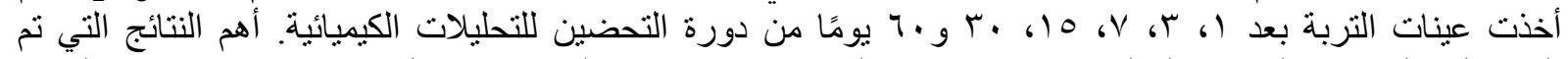

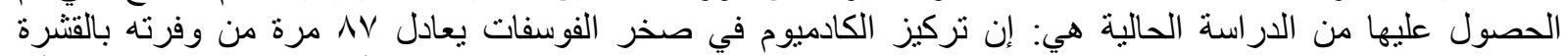

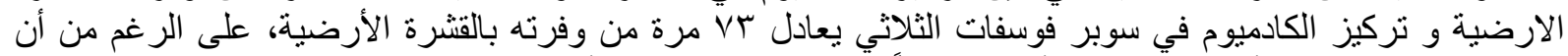

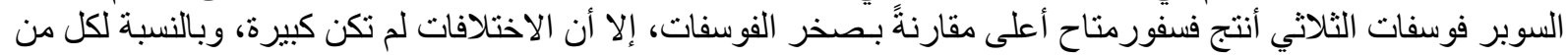

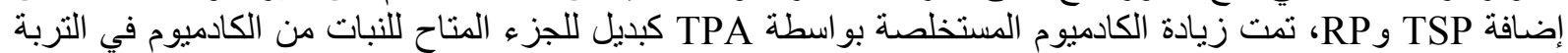

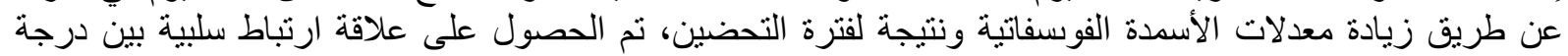

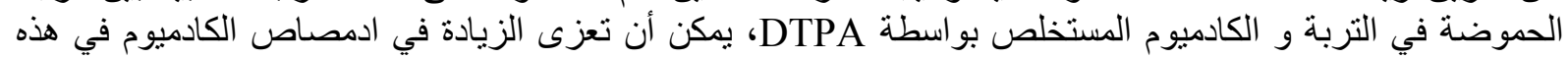

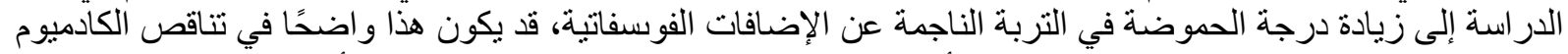

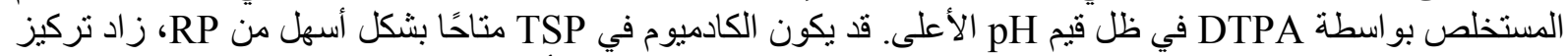

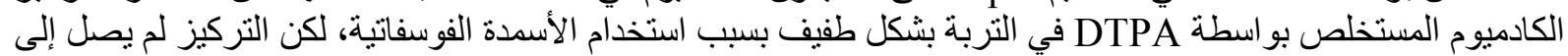
مستويات التلوث تحت المعاملات المختلفة. الكلمات الإسترشادية: الأسمدة الفوسفاتية، الكادميوم، صخر الفوسفات، سوبر فوسفات ثنلاثي. 
